Ambiente \& Água - An Interdisciplinary Journal of Applied Science
ISSN 1980-993X - doi:10.4136/1980-993X
www.ambi-agua.net
E-mail: ambi.agua@gmail.com

\title{
Characterization of automotive shredder residues before and five years after landfill disposal
}

\author{
doi: 10.4136/ambi-agua.1570
}

Received: 28 Nov. 2014; Accepted: 06 Mar. 2015

\author{
Lucian Ionel Cioca $^{1^{*}}$; Larisa Ivascu ${ }^{2}$ \\ 1،Lucian Blaga" University of Sibiu (LBUS), Sibiu, Romania \\ Department of Industrial Engineering and Management \\ ${ }^{2}$ Politehnica University of Timisoara (PUT), Timisoara, Romania \\ Department of Management \\ "Corresponding author: e-mail: lucian.cioca@ulbsibiu.ro, \\ larisa.ivascu@upt.ro
}

\begin{abstract}
The paper illustrates the results of an extensive analytical characterization study of automotive shredder residues (ASR), also known as "fluff". The analyses concerned material fractions and their content, with special reference to heavy metals (e.g. $\mathrm{Cd}, \mathrm{Cr}, \mathrm{Hg}, \mathrm{Pb}, \mathrm{Cu}$ ) and arsenic. Elution tests on the original materials were also conducted. Moreover, chemical concentrations of ASR samples after about five years' landfill residence was assessed, in order to verify possible changes resulting from both in-situ leaching and organic matter degradation phenomena. Results show that lead seems to be the most critical element in view of possible ASR acceptance in non-hazardous waste landfills because of its high concentration in raw waste and, especially, of its proven leachability characteristics.
\end{abstract}

Keywords: automotive shredder residue, elution test, fluff, heavy metal, landfill, leachate.

\section{Caracterização dos resíduos sólidos de automóveis desmantelados antes e depois da disposição em aterro sanitário}

\section{RESUMO}

O artigo ilustra os resultados de um amplo estudo de caracterização analítica dos resíduos sólidos de automóveis desmantelados, também conhecido como "fluff". As análises foram focadas sobre a composição do resíduo e o conteúdo químico das frações individuais, com especial referência aos metais pesados $(\mathrm{Cd}, \mathrm{Cr}, \mathrm{Hg}, \mathrm{Pb}, \mathrm{Cu})$ e arsênico. Também foram realizados testes de eluição sobre os resíduos e frações. Além disso, foi avaliada a composição química de amostras dos resíduos após cerca de cinco anos de permanência no aterro sanitário, para se verificar o nível de alterações devido à lixiviação in-situ e aos fenômenos de degradação da matéria orgânica. Os resultados mostram que o chumbo parece ser o elemento mais crítico, tendo em vista a possível aceitação deste tipo de resíduo sólido em aterros 
sanitários licenciados como resíduos não perigosos, por causa de sua alta concentração nos resíduos brutos e, principalmente, por suas características comprovadas de lixiviação.

Palavras-chave: aterros sanitários, chorume, fluff, resíduos de automóveis, metais pesados, teste de eluição.

\section{INTRODUCTION}

The end-of life vehicles' (ELVs) treatment process involves a preliminary manual separation of potentially dangerous materials (e.g., batteries, fuel, lubricating oils, tires) followed by shredding and mechanical recovery of recyclable materials, e.g., iron, other metals, plastics (Panaitescu et al., 2008; Cioca et al., 2010). What remains after this step, usually termed "Automotive Shredder Residue (ASR)," "auto fluff', or simply "fluff', amounts to about $25 \%$ of the weight of the original vehicle, and it is generally landfilled, although some thermal processes are applied (Vermeulen et al., 2011; Mancini et al., 2014). Landfilling of ASR, and of solid waste in general (Rada et al., 2010) entails significant environmental and health issues mainly due to leachate and biogas production. The main pollutants of leachate are organic compounds, ammonia, and heavy metals. Several combinations of biological processes for ammonia and BOD removal (Farabegoli et al.; 2003; Chiavola et al.; 2010; Raboni et al.; 2013; 2014a; 2014b) with physical-chemical processes for COD, heavy metals and the same ammonia (Raboni et al.; 2013) are generally used for leachate treatment. The biogas produced by ASR landfills is a rather small fraction of the total production of biogas,

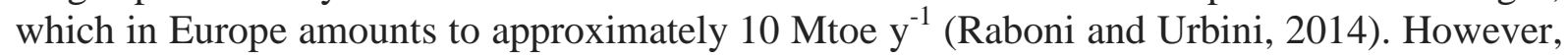
it is characterized by the presence of hazardous organic compounds classified as PAHs and VOCs (Panaitescu et al.; 2008; Raboni et al.; 2015) which are present in the atmosphere of many cities (Ravindra et al., 2013; Torretta et al., 2013b). Due to its high toxicity, many efforts are directed towards the removal of these compounds from waste air streams and in particular biological processes seem very promising (Copelli et al., 2012; Rada et al., 2014a; Torretta et al., 2013a; Ivascu and Cioca, 2014).

There is ongoing debate on the hazardousness of ASR, so that in some cases they are disposed of in landfill for hazardous wastes, while in other cases are disposed of in the same landfill as MSW (Rada et al., 2014b; Torretta et al., 2014). This issue is influenced by available ASR recovery technologies and, more recently, also by changes in vehicles' design, which is more and more oriented toward high material recovery efficiency for ELVs, and alternative engines or fuels (Torres et al., 2013) with the aim of minimizing environmental impact. Such trends are also influenced by European legislation (Directive EC/2000/53 on end-of life vehicles), which promotes suitable vehicle designs in order to facilitate component recovery and recycling. The same Directive foresees that, by January 2015, recovery and recycling targets shall rise to $95 \%$ and $85 \%$, respectively, in order to reduce the role of landfilling.

Literature reports several references concerning ASR chemical-physical characterization, but no results have been found regarding their release of heavy metals after a few years of landfilling.

This paper shows the results obtained by an extensive analytical characterization of ASR samples produced by different Romanian car dismantling companies. Material composition as well as chemicals contents (e.g. heavy metals, arsenic) of both ASR and leachate obtained by standard leachability tests were measured. Moreover, analyses of ASR samples after about five years of landfill residence were carried out, in order to assess changes in their chemical composition after the occurrence of rainwater leaching and organic degradation processes. Such information can also be useful to understand the environmental impact of this type of 
waste in a landfill, and to assess the feasibility of landfill mining practices for the recovery of components to be reintroduced in the recycling market. The paper considers the characterization of this waste after a long period spent in the landfill.

\section{MATERIALS AND METHODS}

ASR generated at several car dismantling companies, located in an industrial area of central Romania, was first collected and mixed; numerous samples were then collected using the quartering method.

Seventy ASR samples were subjected to batch leaching tests using de-ionized water as extractant: the liquid-to-solid ratio was $10 \mathrm{~L} \mathrm{~kg}^{-1}$ total solids (TS). Eluates and washed materials were analyzed in order to evaluate the concentrations of heavy metals $(\mathrm{Cd}, \mathrm{Cr}, \mathrm{Hg}$, $\mathrm{Pb}, \mathrm{Cu}$ ) of interests, in addition to As.

For the characterization of waste, 70 further samples of raw ASR were separated into 7 classes such as: rubber; plastics; paddings; fabrics; metals; others (e.g. paper, rope, wood, leather); fines (residues smaller than $20 \mathrm{~mm}$ ). These samples were submitted to the same tests described for the ASR samples (heavy metals as well arsenic detection in waste and eluate).

Finally, 48 core samples of waste were obtained from 15 boreholes in landfills exclusively dedicated to ASR disposal coming from the very same car dismantling companies, where this waste had been disposed for more than five years. Drilling was performed using the cable-tool percussion technique without circulating fluids in order to obtain chemically undisturbed samples. Sampling depths, ranging from 10 to $25 \mathrm{~m}$ (maximum landfill depth: $30 \mathrm{~m}$ ), corresponded to the estimated position of ASR that was landfilled approximately 6 years before. Afterwards, representative waste samples were taken from the collected core samples to determine their $\mathrm{Cd}, \mathrm{Cr}, \mathrm{Hg}, \mathrm{Pb}, \mathrm{Cu}$ and As content.

Analyses of wastes were made according to standard methods (USEPA, 2014). Analyses of water were made according to Official standard methods for the Examination of Water and Wastewater (APHA et al., 2012).

Statistical analysis of the results was performed in order to estimate mean $(m)$, standard deviation $(s)$ and coefficient of variation $(C V=s / m)$.

\section{RESULTS AND DISCUSSION}

\subsection{ASR composition}

The average composition of analyzed ASR (Figure 1) shows a preponderance of the "fines" fraction, $40.1 \%$ in weight (average value), as found elsewhere in literature, 34-66\% (Cossu et al., 2012). The second most common component is rubber (average value: $19.6 \% \mathrm{wt}$ ), followed by plastics (average value: $13.1 \% \mathrm{wt}$ ). Proportions of metals are very low (average value: $5.1 \% \mathrm{wt}$ ), a fact indicating good separation efficiency of the dismantling process. Such results depend on the degree of shredding and on the material recovery efficiency of the various car dismantling companies.

Moreover, ASR composition shows generally a huge variability: coefficients of variation are greater than 0.50 for all the fractions, except for rubber and metals.

\subsection{Chemicals content of ASR and eluates}

\subsubsection{Raw waste analysis}

The chemical analysis of raw ASR (Figure 2a) shows a significant presence in all samples of lead $\left(5,805 \mathrm{mg} \mathrm{kg}_{\mathrm{TS}}{ }^{-1}\right)$, copper $\left(2,290 \mathrm{mg} \mathrm{kg}_{\mathrm{TS}}{ }^{-1}\right)$ and chromium $\left(278 \mathrm{mg} \mathrm{kg}_{\mathrm{TS}}{ }^{-1}\right)$. In a few samples, arsenic and mercury were also found: their concentration was low but quite 
variable ( $C V$ was equal to 1.36 and 1.82 , respectively). Leachability test results (Figure $2 \mathrm{~b}$ ) emphasize strong leaching of cadmium (about $5 \%$ on average of the total amount found in the raw ASR) even in the face of the small number of positive tests (20\%). Also, lead and chromium showed leaching potential (1.25 and $0.82 \%$, respectively of the total amount found in the raw ASR) in all samples, while arsenic and mercury concentrations were always below the detection limits.

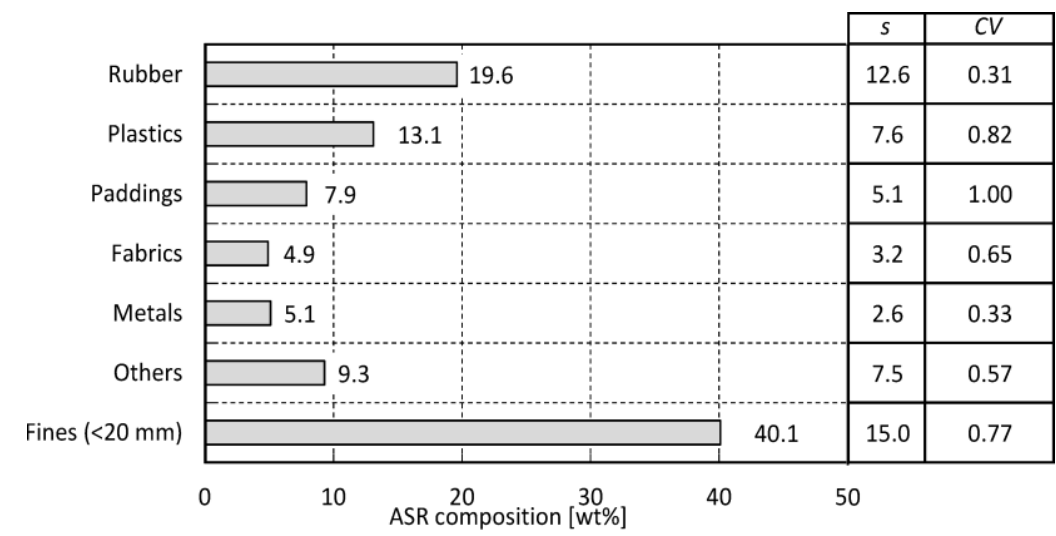

Figure 1. Composition of raw ASR (bars represents the average value, while $s$ and $C V$ are the standard deviation and the coefficient of variation, respectively).

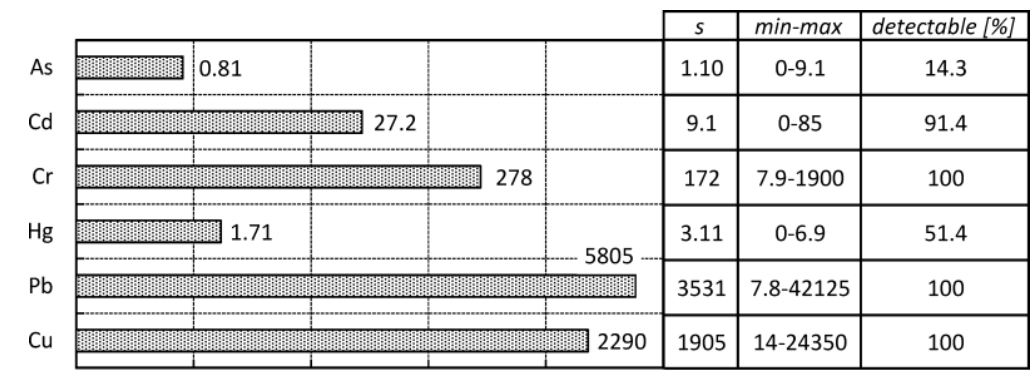

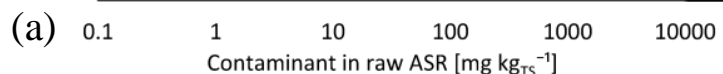

\begin{tabular}{|c|c|c|c|c|c|}
\hline \multirow{2}{*}{\multicolumn{3}{|c|}{ Contaminant in raw ASK [mg kg TS ] }} & \multirow{3}{*}{$\begin{array}{l}s \\
\end{array}$} & \multirow{3}{*}{$\frac{\min -\max }{-}$} & \multirow{3}{*}{\begin{tabular}{|c} 
detectable $[\%]$ \\
0
\end{tabular}} \\
\hline & & & & & \\
\hline As & Not detected & & & & \\
\hline $\mathrm{Cd}$ & 1.56 & & 0.44 & $0-5.6$ & 20.00 \\
\hline $\mathrm{Cr}$ & 2.28 & & 0.96 & $0.8-4$ & 100 \\
\hline $\mathrm{Hg}$ & Not detected & & - & - & 0 \\
\hline $\mathrm{Pb}$ & & & 29.6 & $8-285.2$ & 100 \\
\hline $\mathrm{Cu}$ & 4.00 & & 2.48 & $0-22.4$ & 94.29 \\
\hline DOC & & 42.4 & 24.1 & $55-271$ & 100 \\
\hline
\end{tabular}

(b) $0.1 \quad 1010$ Contaminant in ASR eluate $\left[\mathrm{mg} \mathrm{kg}_{\mathrm{Ts}}{ }^{-1}\right]$

Figure 2. Chemical content in the raw ASR samples (a) and respective eluates (b). Bars represent the average value, while the tables report: standard deviation (s); range (min-max); percentage of samples with concentrations above the instrument detection limit (\% detectable).

\subsubsection{Single materials analysis}

Figures 3, 4 and 5 represent the results found of the single materials composing the raw ASR and their respective eluates. 
Chemical analysis of individual material fractions shows that the "fines" fraction is the major carrier of some contaminants (Figure 5).

As seen for the whole raw ASR (Figure 2a), lead has the highest concentration in every ASR fraction (range: $881-7,120 \mathrm{mg} \mathrm{kg}_{\mathrm{TS}}{ }^{-1}$ ) except for metals, of which copper is the highest one. The presence of lead can be explained by the presence of battery fragments or electrolytes, lead-based pigments, weldings, bearings, stabilizers for plastics and rubber. The high concentration of copper in the metallic fraction is most likely due to cable residuals, which were found in the waste.
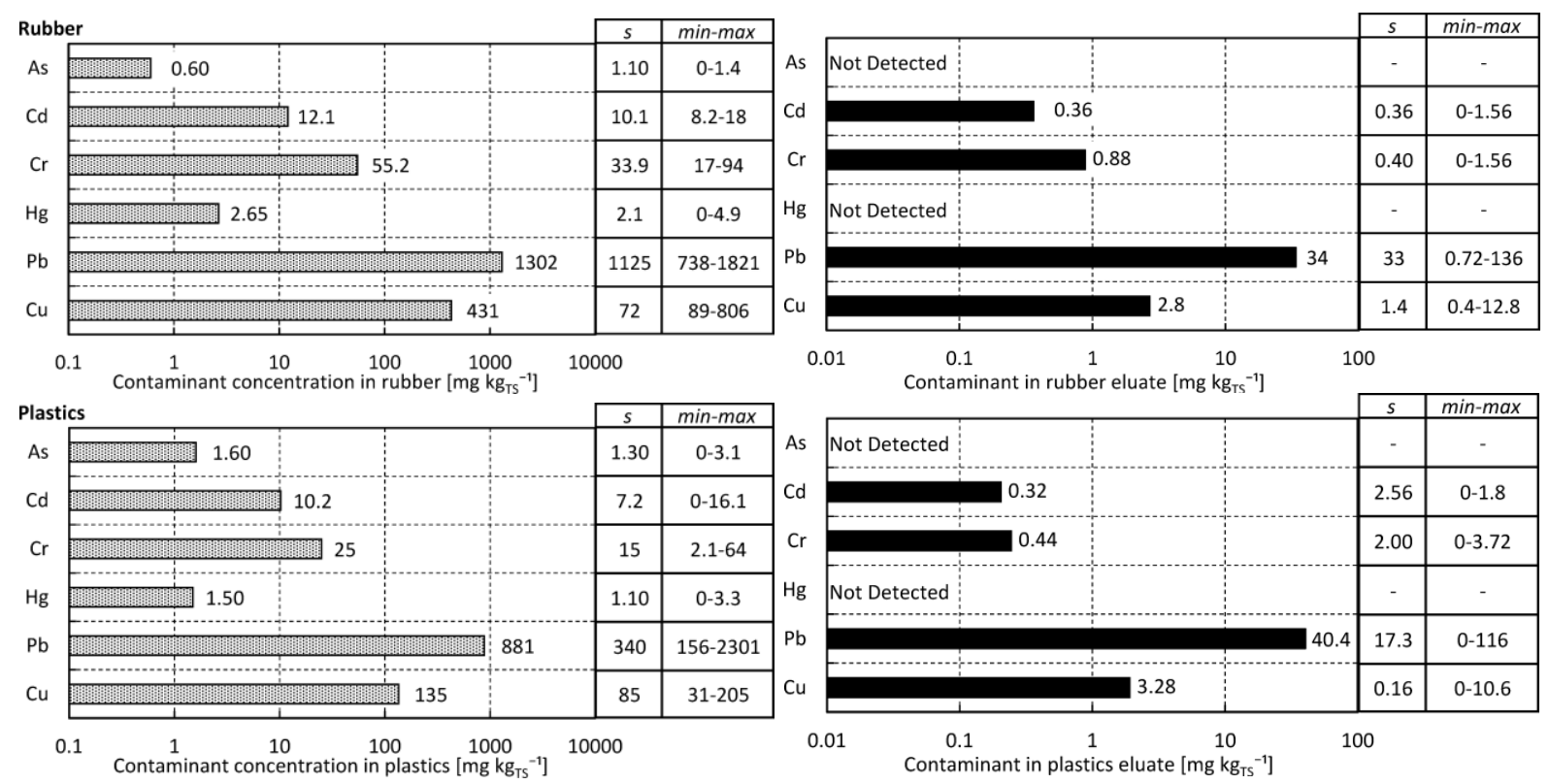

Figure 3. Contaminants concentration in rubber and plastics (left) including the respective eluates (right).
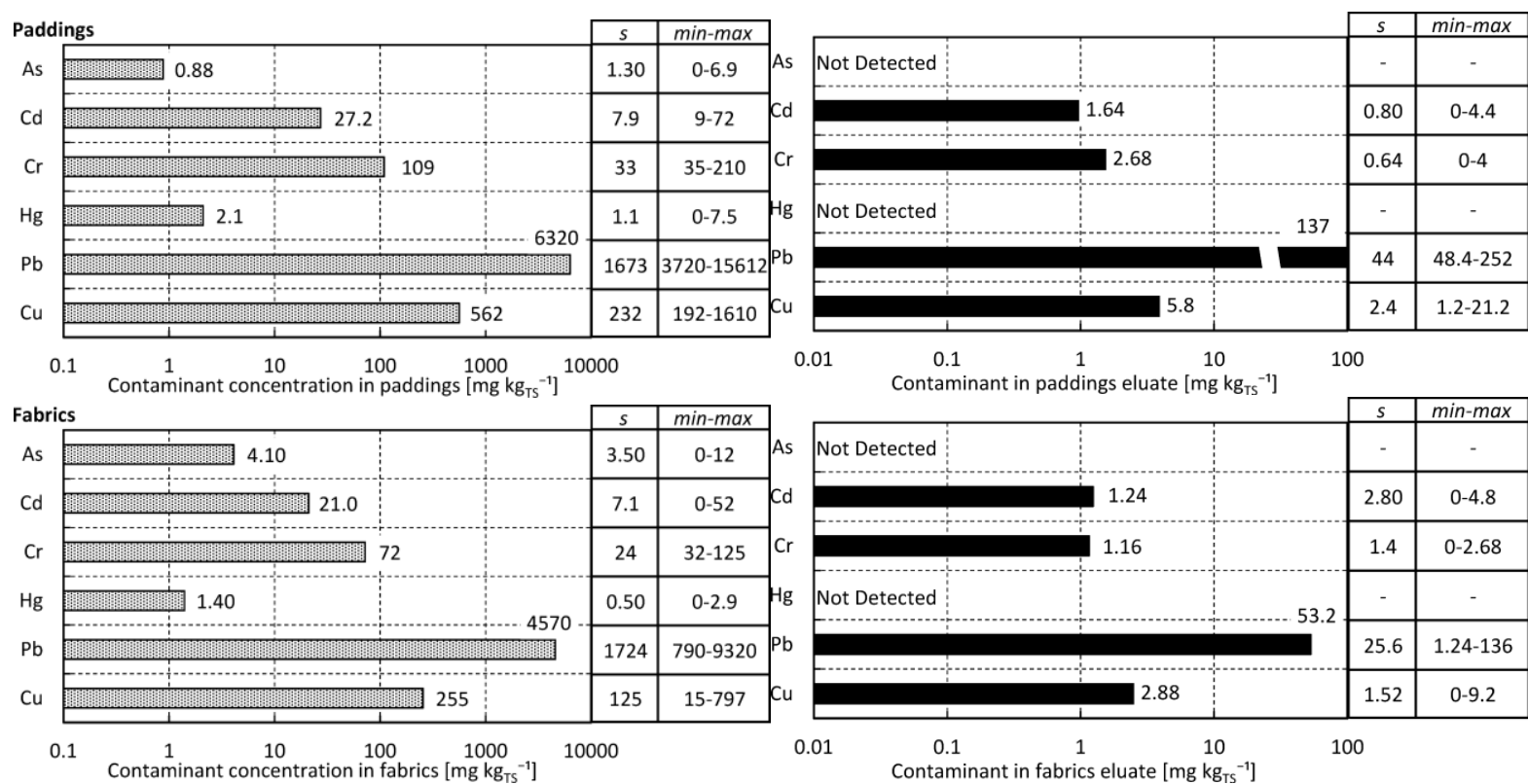

Figure 4. Contaminants concentration in paddings and fabrics (left) including the respective eluates (right).

Concerning the eluates, lead is the most mobile pollutant, especially in paddings (Figure 4), followed by copper. Arsenic and mercury were not detected in the ASR eluate 
fractions. The widespread presence of such heavy metals in all fractions is likely to be determined by the "fines" and the contaminated fluids' (e.g. battery electrolytes) dispersion into the ASR. This outcome validates the treatment solution proposed by some authors, which consists of ASR washing prior to landfilling (Cossu et al., 2012).
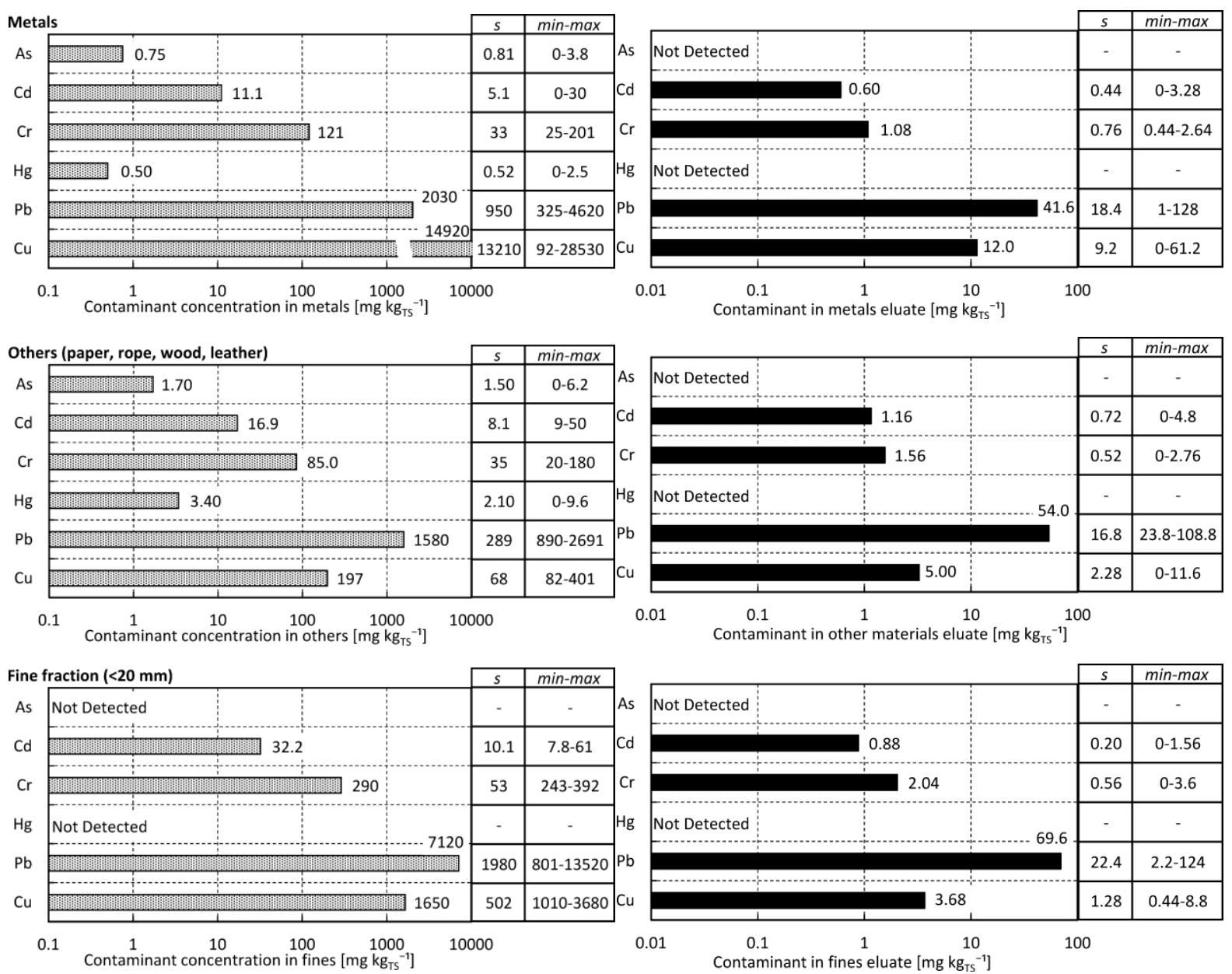

Figure 5. Contaminants concentration in metals, other materials and fine fraction (left) including the respective eluates (right).

\subsection{Chemical content in samples five years after landfill disposal}

Figure 6 shows the concentration frequency histograms concerning the three most significant pollutants found in ASR samples cored five years after landfilling: cadmium, copper and lead. Cadmium concentration has a typical normal distribution (Figure 6a), while both copper and lead have a lognormal one (Figure $6 \mathrm{~b}$ and $6 \mathrm{c}$ ). Such findings demonstrate the homogeneous presence of the heavy metals in the ASR waste, which could be justified by the following phenomena: percolating lead-batteries liquids; water leaching, which distributes the "fines" (the most polluted fraction) into the waste. Comparing the results to the average concentrations found in the original raw ASR (Figure 2a), lead seems to have undergone the major leaching effect (just less than $60 \%$ of loss on average), while cadmium and copper had not been mobilized at all (less than $2 \%$ of loss on average). 
(a)

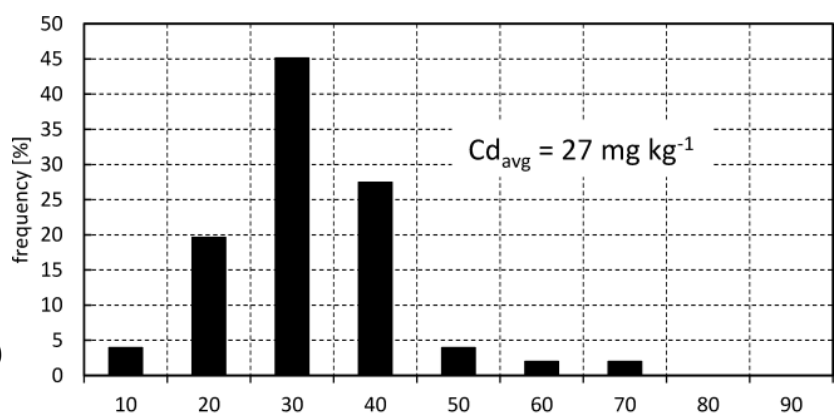

(b)
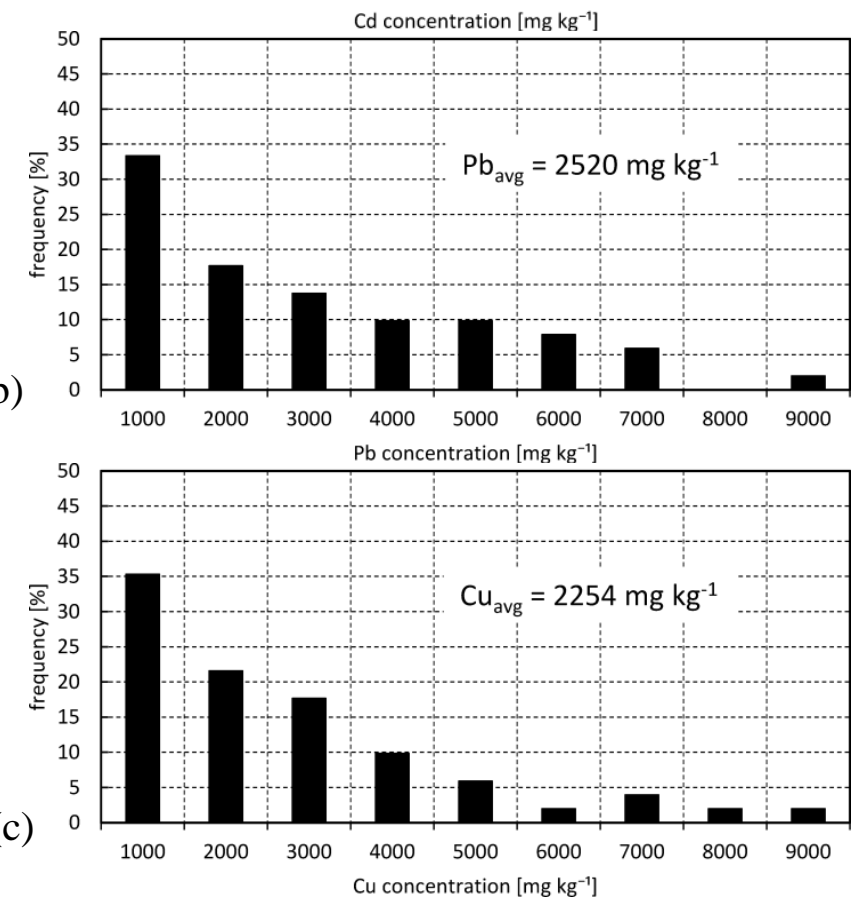

Figure 6. Frequency histograms and average values for cadmium (a), lead (b) and copper (c) concentration in ASR samples after 5 years of landfilling.

\section{CONCLUSIONS}

Analyses carried out on automotive shredder residues samples before landfill disposal revealed a preponderant presence of the "fines" fraction (particles smaller than $20 \mathrm{~mm}$ ) in which most contaminants are also concentrated. Their composition showed an enormous variability (coefficient of variation greater than 0.5, except for "fines"). Moreover, "fines" were found dispersed and absorbed in all fractions, paddings in particular.

Lead is the most abundant heavy metal, with average and peak concentrations of 5,805 and $42,125 \mathrm{mg} \mathrm{kg}_{\mathrm{TS}}{ }^{-1}$, respectively. Significant presence of copper and cadmium was also found. Leachability tests with de-ionized water prove that lead is the most critical element that may preclude the acceptance of automotive shredder residue in non-hazardous waste landfills, according to European regulations. Lead was found in $100 \%$ of the examined eluate samples, at mean and maximum concentrations of about 72 and $285 \mathrm{mg} \mathrm{kg}_{\mathrm{TS}}{ }^{-1}$, respectively.

Tests on cored samples after about five years from landfill disposal also confirmed the strong leaching of lead, likely due to "fines" washing and the anomalous presence of lead-battery fragments or liquids.

Analyses confirm the critical issues connected with the disposal of automotive shredder residues in non-hazardous landfills, due to a high presence of heavy metals (mainly: lead; secondarily: copper and cadmium) and the possibility of their significant release over time, as 
confirmed by elution tests on raw and "seasoned" ASR. A possible solution may entail the adoption of more careful recovery and recycling processes (e.g. ASR washing prior to landfilling), as well as more efficient "fines" separation before the landfill disposal of residues.

\section{REFERENCES}

AMERICAN PUBLIC HEALTH ASSOCIATION - APHA; AMERICAN WATER WORKS ASSOCIATION - AWWA; WATER ENVIRONMENTAL FEDERATION - WEF. Standard methods for the examination of water and wastewater. $22^{\text {th }} \mathrm{ed}$. Washington, DC, 2012.

CHIAVOLA, A.; BACIOCCHI, R.; GAVASCI, R. Biological treatment of PAHcontaminated sediments in a Sequencing Batch Reactor. Journal of Hazardous Materials, v. 184, n. 1-3, p. 97-104, 2010.

http://dx.doi.org/10.1016/j.jhazmat.2010.08.010.

CIOCA, L. I.; MORARU, R.; BABUT G. Occupational risk assessment: a framework for understanding and practical guiding the process in Romania. In: INTERNATIONAL CONFERENCE ON RISK MANAGEMENT, ASSESSMENT AND MITIGATION RIMA'10, 2010, Bucharest. Proceedings... Bucharest: Universitatea Politehnica, 2010. p. $56-61$

COPELli, S.; TORRETTA, V.; RABONI, M.; VIOTTI, P.; LUCIANO, A.; MANCINI, G. Improving biotreatment efficiency of hot waste air streams: Experimental upgrade of a full plant. Chemical Engineering Transactions, v. 30, p. 49-54, 2012. http://dx.doi.org/10.3303/CET1230009.

COSSU, R.; LAI, T.; PIVNENKO, K. Waste washing pre-treatment of municipal and special waste. Journal of Hazardous Materials, v. 65-72, p. 207-208, 2012. http://dx.doi.org/10.1016/j.jhazmat.2011.07.121.

FARABEGOLI, G.; GAVASCI, R.; LOMBARDI, F.; ROMANI, F. Denitrification in tertiary filtration: Application of an up-flow filter. Journal of Environmental Science and Health - Part A Toxic/Hazardous Substances and Environmental Engineering, v. 38, n. 10, p. 2169-2177, 2003. http://dx.doi.org/10.1081/ESE-120023349.

IVASCU, L.; CIOCA, L. I. Opportunity risk: integrated approach to risk management for creating enterprise opportunities. Advances in Education Research, v. 49, n. 1, p. 77 80, 2014.

MANCINI, G.; VIOTTI, P.; LUCIANO, A.; RABONI, M.; FINO, D. Full scale treatment of ASR wastes in a modified rotary kiln. Waste management, v. 34, n. 11, p. 2347-2354, 2014. http://dx.doi.org/10.1016/j.wasman.2014.06.028.

PANAITESCU, D.; IORGA, M.; CIUCU, A.; SERBAN, S.; CRUCEAN, A.; BERCU, C. New methods for recycling plastic materials from end-of-life vehicles. WSEAS Transactions on Environment and Development, v. 4, n. 12, p. 1009-1108, 2008.

RABONI, M.; TORRETTA, V.; VIOTTI, P.; URBINI, G. Experimental plant for the physical-chemical treatment of groundwater polluted by municipal solid waste (MSW) leachate, with ammonia recovery. Revista Ambiente \& Água, v. 8, n. 3, p. 22-32, 2013. http://dx.doi.org/10.4136/ambi-agua.1250. 
RABONI, M.; URBINI G. Production and use of biogas in Europe: a survey of current status and perspectives. Revista Ambiente \& Água, v. 9, n. 2, p. 191-202, 2014. http://dx.doi.org/10.4136/ambi-agua.1324.

RABONI, M.; TORRETTA, V.; VIOTTI, P.; URBINI, G. Pilot experimentation with complete mixing anoxic reactors to improve sewage denitrification in treatment plants in small communities. Sustainability, v. 6, n. 1, p. 112-122, 2014a. http://dx.doi.org/10.3390/su6010112.

RABONI, M.; TORRETTA, V.; VIOTTI, P.; URBINI, G. Calculating specific denitrification rates in pre-denitrification by assessing the influence of dissolved oxygen, sludge loading and mixed-liquor recycle. Environmental Technology, v. 35, n. 20, p. 25822588, 2014b. http://dx.doi.org/10.1080/09593330.2014.913690.

RABONI, M.; TORRETTA, V.; URBINI, G.; VIOTTI, P. Automotive shredder residue: a survey of the hazardous organic micro-pollutants spectrum in landfill biogas. Waste Management and Research, v. 33, n. 1, 2015. http://dx.doi.org/10.1177/0734242X14559300.

RADA, E. C.; ISTRATE, I. A.; PANAITESCU, V.; RAGAZZI, M.; CIRLIORU, T.; APOSTOL, T. A comparison between different scenarios of Romanian municipal solid waste treatment before landfilling. Environmental Engineering Management Journal, v. 9, n. 4, p. 589-596, 2010.

RADA, E. C.; RABONI, M.; TORRETTA, V.; COPELLI, S.; RAGAZZI, M .; CARUSON, P. Removal of benzene from oil refinery wastewater treatment plant exchausted gases with a multi-stage biofiltration pilot plant. Revista de Chimie, v. 65, n. 1, p. 68-70, 2014a.

RADA, E. C.; RAGAZZI, M.; IONESCU, G.; MERLER, G.; MOEDINGER, F.; RABONI, M.; TORRETTA, V. Municipal Solid Waste treatment by integrated solutions: Energy and environmental balances. Energy Procedia, v. 50, p.1037-1044, 2014b. http://dx.doi.org/10.1016/j.egypro.2014.06.123.

RAVINDRA, K.; SOKHI, R.; VAN GRIEKEN, R. Atmospheric polycyclic aromatic hydrocarbons: Source attribution, emission factors and regulation. Atmospheric Environment, v. 42, n. 13, p. 2895-2921, 2013.

http://dx.doi.org/10.1016/j.atmosenv.2007.12.010.

TORRES, E. A.; CERQUEIRA, G. S.; FERRER, T. M.; QUINTELLA, C. M.; RABONI, M.; TORRETTA, V. et al. Recovery of different waste vegetable oils for biodiesel production: a pilot experience in Bahia State, Brazil. Waste management, v. 33, p. 2670-2674, 2013. http://dx.doi.org/10.1016/j.wasman.2013.07.030.

TORRETTA, V.; RABONI, M.; COPELLI, S.; CARUSON, P. Application of multi-stage biofilter pilot plants to remove odor and VOCs from industrial activities air emissions. In: Int. Conf. on Energy and Sustainability, 4. 19-21 Jun 2013, Bucharest, Romania. WIT Transactions on Ecology and the Environment, v. 176, p. 225-233, $2013 \mathrm{a}$. http://dx.doi.org/10.2495/ESUS130191. 
TORRETTA, V.; IONESCU, G.; RABONI, M.; MERLER, G. The mass and energy balance of an integrated solution for municipal solid waste treatment. In: INTERNATIONAL CONFERENCE ON WASTE MANAGEMENT AND THE ENVIRONMENT, 7., 1214 May 2014, Ancona, Italy. WIT Transactions on Ecology and the Environment, v. 180, p. 151-161, 2014. http://dx.doi.org/10.2495/WM140131.

TORRETTA, V.; RABONI, M.; COPELLI, S.; RADA, E. C.; RAGAZZI, M.; IONESCU, G. et al. Application of strategies for particulate matter reduction in urban areas: an Italian case. UPB Scientific Bulletin, Series D: Mechanical Engineering, v. 75, n. 4, p. 221228, 2013b.

UNITED STATES. Environmental Protection Agency - USEPA. Test methods for evaluating solid waste, physical/chemical methods, SW-846. Available in: <http://www.epa.gov/osw/hazard/testmethods/sw846>. Access in: Nov. 2014.

VERMEULEN, I.; VAN CANEGHEM, J.; BLOCK, C.; BAEYENS, J.; VANDECASTEELE, C. Automotive shredder residue (ASR): reviewing its production from end-of-life vehicles (ELVs) and its recycling, energy or chemicals' valorisation. Journal of Hazardous Materials, v. 190, n. 8-27, 2011. http://dx.doi.org/10.1016/j.jhazmat.2011.02.088. 